This is a postprint version of the following published document:

Carlos Álvarez Nogal, C. and Chamley, Christophe (2014). Debt policy under constraints between Philip II, the Cortes and Genoese bankers. Economic History Review, v. 67, n. 1, pp. 192-213. Available in: http://dx.doi.org/10.1111/1468-0289.12010

(c) Wiley 


\title{
Debt policy under constraints: Philip II, the Cortes, and Genoese bankers ${ }^{1}$
}

\author{
By CARLOS ÁLVAREZ-NOGAL and CHRISTOPHE CHAMLEY*
}

\begin{abstract}
Under Philip II, Castile was the first country with a large nation-wide domestic public debt. A new view of that fiscal system is presented that is potentially relevant for other fiscal systems in Europe before 1800. The credibility of the debt, mostly in perpetual redeemable annuities, was enhanced by decentralized funding through taxes administered by cities making up the Realm in the Cortes. The accumulation of short-term debt depended on refinancing through long-term debt. Financial crises in the short-term debt occurred when the service of the long-term debt reached the revenues of its servicing taxes. They were not caused by liquidity crises and were resolved after protracted negotiations in the Cortes by tax increases and interest rate reductions.
\end{abstract}

K ing Philip II, as head of the first modern super-power, managed a budget on a scale that had not been seen since the height of the Roman Empire. ${ }^{2}$ No state before had faced such extraordinary fluctuations and imbalances, both in revenue and expenditure. Large military expenses were required by the politics of Europe and the revolution in military technology. The variability in both revenue and expenses, coupled with a large foreign component, was met by large public borrowings up to modern levels, a historical innovation that, in later centuries, would be followed by the Netherlands, France, and England. Like eighteenthcentury England, Castile (about 80 per cent of modern-day Spain) established its military supremacy through its superior ability to mobilize large resources through borrowing.

The debt-to-GDP ratio exceeded 50 per cent, according to some estimates, and the ratio between interest service and tax revenues at the end of the century was about 50 per cent, as it would be in England or France two centuries later. ${ }^{3}$ These impressive numbers were achieved without a central administration to collect tax

\footnotetext{
* Author affiliations: Carlos Álvarez-Nogal, Universidad Carlos III de Madrid; Christophe Chamley, Boston University and PSE.

${ }^{1}$ We would like to thank Jean-Laurent Rosenthal, Gilles Postel-Vinay, Pierre-Cyrille Hautcoeur, Leandro Prados de la Escosura, and the referees for their comments and suggestions. Financial support was received from the HI-POD Project, European Commission's Seventh Research Framework Programme and Ministry of Economy and Competitiveness (Spain) HAR2012-39034-C03-02.

${ }^{2}$ At 6 million ducats (the average around 1560), with a ducat at 35 grams of silver, it amounted to 210 tons of silver per year with a population of about 5 million, while the Roman Empire's budget was between 500 and 1,000 tons for a population of 50 million; Hopkins, 'Rome'. The size of the monetized government revenues and expenditures, per capita, had been small throughout the middle ages in western Europe; Bean, 'War'.

${ }^{3}$ Álvarez-Nogal and Prados de la Escosura, 'Decline of Spain', pp. 352-4.
} 
revenues and without a centralized capital market that could facilitate the management of the public debt. ${ }^{4}$

Under Philip II, four 'defaults' are alleged to have occurred, and these financial crises have attracted considerable attention. We propose an interpretation of the financial crises under Philip II that is totally new. These crises were not caused by a 'sudden stop' from foreign bankers, by a problem of liquidity, or by the inability of the Crown to raise sufficient revenues. Since the crises that took place concerned loans with Genoese bankers, all previous studies have focused on relations between the Crown and the bankers. We show that the cause of each of the crises lay elsewhere, in the protracted negotiations about higher taxes that took place in the Cortes between the Crown and the cities of Castile.

In a decentralized system with no central administration, the cities managed the taxes that serviced the most secure component of the domestic debt, and these taxes effectively put a ceiling on the domestic debt. Any significant accumulation of loans with foreign bankers had to be converted eventually into domestic debt. When the service of that debt reached the implicit ceiling imposed by the domestic taxes, protracted negotiations had to take place between the Crown and the cities. These negotiations triggered a suspension of payments by the Crown on the loans with foreign bankers.

In our argument, the alleged defaults were part of a system that had efficient properties in the institutional context. Our argument focuses on the economics, but it also sheds some light on the political state of Castile, and on the development of states and their finances in early modern Europe, especially for composite monarchies of the kind exemplified by Castile. ${ }^{5}$

The public debt had been created and developed gradually by Italian cities since the twelfth century. ${ }^{6}$ Within a city-state, a credible public debt could be issued because debt holders had some control over the collection of taxes that would service that debt. The Italian system was extended in the Netherlands under Philip II's father, Charles V: the state's debt was issued through the cities that were part of a central political regime. ${ }^{7}$ In this way, bondholders kept control of the revenues that would service the debt. In Castile, that system was introduced by Charles V and developed further under Philip II. The dominant part of the debt was the domestic debt, called juros, and the main part of the juros was administered by cities that controlled taxes. Hence, the lack of a central administration which would control and enforce tax revenues did not diminish but reinforced the capability of the Crown to borrow because it restricted its ability to divert tax revenues away from servicing the debt.

The domestic debt provided collateral, either implicit or explicit, for the shortterm debt, the asientos, which could be converted into long-term juros. Following the routine established in the previous century, ${ }^{8}$ the Crown converted any significant accumulation of short-term debt into long-term domestic debt. Each city contributed a fixed lump-sum amount per year that was established, by majority

\footnotetext{
${ }^{4}$ In England, both the tax administration and capital markets developed only after the Glorious Revolution; Brewer, Sinews; Dickson, Financial revolution.

${ }^{5}$ This issue has been the subject of a number of important recent studies that cannot be summarized here. We provide references on specific issues.

${ }^{6}$ Pezzolo, 'Government debts'.

${ }^{7}$ Tracy, Financial revolution; Gelderblom and Jonker, 'Public finance'.

${ }^{8}$ Andrés Díaz, El último decenio.
} 
vote, at the meeting of 18 cities in the Cortes. Hence, the total contribution established a de facto ceiling on the service of the public debt. When the domestic debt grew and the ceiling was reached, the short-term debt could no longer be converted into long-term debt and a crisis took place. This structure explains both the existence of a large, credible domestic debt and the repeated crises.

Each of the three financial crises under Philip II (in 1557-60, 1575-7, and 1596-7) formally started when the Crown declared a suspension of payments on short-term loan contracts, the asientos. ${ }^{9}$ However, each crisis occurred when the service of the long-term debt reached the previously agreed-upon ceiling of the city tax payments. ${ }^{10}$ The crises had no adverse effect on the long-term debt interest rate, which declined during the century.

Previous works on the financial crises in sixteenth-century Castile fall into one of two categories. The first category, favoured especially by economists, views Castile as a modern state with central control over expenditures and revenues and a budget policy that could be evaluated by aggregates according to International Monetary Fund criteria. ${ }^{11}$ Some economists even interpret the so-called 'defaults' of the late sixteenth century as proper solvency crises that resulted from an incompatibility of revenue-raising capacity and expenditure. ${ }^{12}$ More recently, Drelichman and Voth, following earlier work by Thompson and others, have shown that solvency was never the issue, from the point of view of a centralized government, but that instead these crises were liquidity crises followed by renegotiations and a conversion of short-term loans into long-term bonds. ${ }^{13}$

We agree that solvency was not the issue, but we do not think that the crises under Philip II were short-term liquidity crises. ${ }^{14}$ In a standard liquidity crisis, lenders refuse to provide additional short-term lending or loan roll-overs. However, each of the crises was not triggered by such a constraint but instead by a suspension of payments declared by Philip II. The most important crisis, in 1575, could have been avoided easily if Philip II had asked for a moderate increase of tax revenues from the cities instead of embarking on a power play to triple these revenues.

The second category of historical research on Spain follows Elliott in emphasizing the 'composite' nature of the state in which territories preserved most of their political-administrative structure and historic freedoms. ${ }^{15}$ We support this view and argue that relations between the Crown and the cities were directly related to the dealings between the Crown and the Genoese bankers who provided

\footnotetext{
${ }^{9}$ The two crises of 1557 and 1560 are actually two parts of the same crisis.

${ }^{10}$ The process is reminiscent of the deadlock that almost took place in the summer of 2011 in the US between the legislative and the executive branch of the government.

${ }^{11}$ Lovett, 'Castilian bankruptcy'; Conklin, 'Theory of sovereign debt'; Drelichman and Voth, 'Sustainable debts'.

${ }^{12}$ Reinhart and Rogoff, This time is different.

${ }^{13}$ Drelichman and Voth, 'Sustainable debts'; Thompson, 'Castile'.

${ }^{14}$ For example, the statement that 'a compromise [between Philip II and the Cortes] emerged in 1575, too late to prevent a default on short-term debt' (Drelichman and Voth, 'Sustainable debts', p. 816) is contrary to historical evidence of the protracted negotiations that we discuss in our detailed account of the 1575 crisis in section $\mathrm{V}$.

${ }^{15}$ Elliott, 'Europe'; Grafe, Distant tyranny; Artola, La Hacienda; Gelabert, La bolsa del rey; Sanz Ayán, 'Procedimientos'; Tracy, Emperor Charles V; Irigoin and Grafe, 'Bargaining for absolutism'.
} 
short-term loans. ${ }^{16}$ In order to understand the financial crises it is important to study both relationships at the same time.

In this article, we also provide a new description of the actual nature of the financial crises under Philip II. Traditionally, the literature has labelled them bankruptcies. ${ }^{17}$ Such a Procrustean classification neglects the historical features of financial instruments in Castile and confuses interest reduction with debt reduction. Most of the domestic debt was in perpetual annuities redeemable at par (juros al quitar): the Crown could repay the principal at any time. This feature had been introduced in the fifteenth century and, by the end of that century, the Crown was routinely using the redeemability of the annuities to lower their interest rate as the market rate decreased gradually over the century. Each interest reduction was not forced and included the provision that the debt holder could choose instead the cash payment of the face value of the principal.

Although interest reductions were indeed conducted during the crisis resolutions of 1575-7 and 1596-7, they were not defaults, as is often alleged. We certainly do not deny that some of the debt was reduced, but we think that the quoted amounts (for example, those given by Drelichman and Voth) are overstated. ${ }^{18}$ More work is needed on this issue, however.

The article is organized along the following lines. The backbone of the system, the long-term domestic juros, is presented in section I. The funding of the juros is analysed in Section II. Section III is devoted to the short-term debt, the asientos. Section IV discusses principles of fiscal and debt policy under the constraint of a quantum cost of adjusting taxes. A mathematical formulation of the fiscal problem is beyond the scope of this article and could not do full justice, at this stage, to the complexity of the interactions between the Crown, the cities, and the Genoese bankers. In the context of a quantum cost of adjustment, some accumulation of short-term debt can be efficient despite its higher cost, and it is entirely converted into long-term debt when there is a tax adjustment. Indeed this actually occurred under Philip II. In section V, each of the three crises is analysed in light of our main argument.

\section{I}

The core of the fiscal system of Castile was its long-term debt. In order to understand its funding mechanism and the interest reductions on the debt, it is necessary to examine the financial instruments of this long-term debt, called juros. They had been introduced in the twelfth century as pension rewards for services during the Reconquista. ${ }^{19}$ Their marketability increased gradually over the centuries. Given the stage of development and the institutions in the sixteenth century, there was no central market with price quotations as, centuries later, there would

\footnotetext{
${ }^{16}$ Historians have either specialized in the relations between the Crown and the Cortes (for example, Fortea Pérez, Monarquía y Cortes), or in the relations between the Crown and the bankers (Carlos Morales, Felipe II, and the cited literature).

${ }^{17}$ Reinhart and Rogoff, This time is different.

${ }^{18}$ A central point made by Drelichman and Voth is that Genoese bankers did rather well on their loans, ex post, in spite of the debt reductions. Our argument about interest reduction reinforces their conclusion.

${ }^{19}$ See Barthe Porcel, Los juros; Toboso Sánchez, La deuda pública; Pérez-Prendes and Torres López, Los juros.
} 
be in the Netherlands and England. More importantly, in the political structure of Castile, there could not be such a market. The juros were serviced at the city level to ensure their credibility. Thus, for a juro issued in Seville, the coupons had to be collected in Seville and not in Madrid. The same office would service the juros and collect the local sales tax revenues on which the service of juros had first claim. Furos were also ranked by local order of seniority according to their date of issuance. No default took place on juros in the sixteenth century, but there could be local delays of payment. Furos were traded and not attached to a particular holder (transactions had to be registered). They were not homogeneous like the 3 or 4 per cent annuity found in eighteenth-century England, but they could be traded throughout the entire realm..$^{20}$

furos were either perpetual and redeemable annuities (juros al quitar), or life annuities (juros de por vida), which were also redeemable. ${ }^{21}$ furos al quitar had a face value, the principal, which could be paid back by the government at any time. The redeemable feature enabled the government to reduce the debt in times of surplus and to refinance when the interest rate decreased. Such interest reductions had taken place in the fifteenth century, from 10 to 7 per cent and from 8 to 6 per cent. At the same time, the Crown sold new juros at rates of 7 and 6 per cent. ${ }^{22}$

Redeemable annuities with a fixed income complied with the usury laws of the church that essentially aimed at preventing a state of servitude of the debtor. In later centuries (for example, in France in the seventeenth century and England in the eighteenth century), refinancing at a lower interest rate was achieved by a reduction of the coupon while keeping the face value of the loan unchanged. ${ }^{23}$ In Castile, following the tradition established in the previous century, the interest reduction kept the annual income constant and demanded from the lender an augmentation of the capital of the loan, known as the crecimiento. A juro was defined by the capital amount needed to generate 1,000 maravedis (mrs). For example, '14,000 al millar' means an interest of 7.14 per cent. In a crecimiento, the holder of the juro was given the choice between either receiving its face value in cash, or paying the difference with the new face value. In a reduction from 7.14 to 5 per cent, the holder of a juro that was 'increased' to 20,000 had to make a payment of 6,000 in order to keep the juro. In such cases, the new face value would be registered. ${ }^{24}$

The crecimiento may also have provided a commitment device against a forced debt reduction, since a forced increase of a bond's capital value is perhaps more difficult to implement than a decrease of a bond's coupon. ${ }^{25}$ No juro had its annual income reduced during the reign of Philip II. Crecimientos are a central issue in the interpretation of the resolution of the crises of 1575-7 and 1596-7.

\footnotetext{
${ }^{20}$ The Netherlands did not have a central bond market at that time either. Issuances were at the local level as in Castile; van Bochove, 'Intermediaries'.

${ }^{21}$ The fraction of juros al quitar was $76 \%$ in $1559,82 \%$ in 1575 , and about $90 \%$ at the end of the century; Artola, La Hacienda, p. 88.

${ }^{22}$ Andrés Díaz, El último decenio.

${ }^{23}$ Chamley, 'Interest reductions'.

${ }^{24}$ The market value of old juros (that carry a high dividend ratio) depended on the long-term rate and on the expectation about future crecimientos, in addition to local conditions.

${ }^{25}$ In a similar sense, tontines were more vulnerable than life annuities and were indeed reduced to life annuities by Joseph Marie Terray, Controller-General of Finances during the reign of Louis XV in France, in his debt reduction of 1770 .
} 
The funding of the domestic debt should, above all, have a stable basis. The standard method of increasing credibility, since the creation of the public debt in the Italian cities during the middle ages, has been an alignment between the debt holders and the people who control and enforce the taxes that service the debt. ${ }^{26}$ What was good for a city-state could also be used by a state that included cities. The Italian system was generalized in the sixteenth century to states that included cities. ${ }^{27}$ In Castile, the system of 'borrowing through cities' had an ideal setting: most of the Castilian realm was represented by 18 cities and their surrounding regions, and negotiations between the Crown and the realm were centralized in the Cortes.

The main tax in Castile was the alcabalas, a sales tax collected by tax farming before 1536, with a nominal rate of 10 per cent (de facto a legal maximum). ${ }^{28}$ The actual rate was much lower, possibly around 2 per cent. ${ }^{29}$ The Cortes of 1536 established the system of the encabezamiento general by which each city was committed to an annual lump-sum payment that was fixed for the following six years. These amounts were adopted in the Cortes by majority voting. Each readjustment of the encabezamientos would require protracted negotiations. After 1536, the encabezamiento provided the most stable basis for servicing the juros.

The lack of a central administration to collect the alcabalas directly prevented the central government from diverting revenues away from servicing the debt. It thus enhanced the borrowing capability of the government. The delegation of tax revenues and the debt service was a commitment device that enabled the Crown to increase the domestic debt to a level that was unprecedented in the sixteenth century.

Furos were administered by cities, but they were legal contracts between holders and the Crown, rather than contracts between holders and cities. Hence, they could be traded throughout the entire realm with registered sales and transfers. ${ }^{30}$ Because of the delegation of revenue collection, there was no centralized market (as in eighteenth-century England) and it should not be surprising that the coupon rates for apparently similar juros were not identical.

The alcalabas and the associated servicios (see below) represented the most stable basis for the funding of the debt, but they were only part of the Crown's revenues. An overview of these revenues is presented in table 1 according to their capacity for debt servicing. The table is in four parts, each defined by its reliability for servicing the public debt. On the left-hand side are the ordinary revenues, which provided a stable source of funding. At the top is the fixed contribution of cities, which was determined in the Cortes, and provided the most reliable base. Below are the taxes that were administered directly by the Crown (for example, import duties and monopolies), which were less reliable. On the right-hand side are the extraordinary revenues, which were of two types. At the top are the city

\footnotetext{
${ }^{26}$ Pezzolo, 'Government debts'.

${ }^{27}$ For the Low Countries under Carlos V, see Tracy, Financial revolution, esp. pp. 71-108. In 1522, Francis I issued the Rentes sur l'Hôtel de Ville de Paris; Vührer, Histoire.

${ }^{28}$ Zabala Aguirre, Las alcabalas, p. 57.

${ }^{29}$ Artola, La Hacienda, p. 50.

${ }^{30}$ Archivo Histórico Nacional, Madrid (hereafter AHN), Consejos Juros, leg. 1733, fo. 7; AGS, Contaduría de Mercedes, leg. 227.
} 
Table 1. Types of revenue

\begin{tabular}{llllr}
\hline & \multicolumn{1}{c}{ Ordinary } & Share & Extraordinary & Share \\
\hline Cortes & Fixed contributions (alcabalas) & $27 \%$ & Temporary contributions & $8 \%$ \\
Non-Cortes & Taxes set by the Crown & $24 \%$ & Other revenues & $22 \%$ \\
& & & Silver from the Indies & $19 \%$ \\
\hline
\end{tabular}

Notes: Shares of revenues varied over time. The table presents averages for the entire tenure of Philip II (1556-98). Temporary contributions include servicio ordinario and extraordinario and the millones (which were in place only between 1591 and 1596). Other revenues include arbitrios (occasional revenues) and church revenues (on average 17\%). Negotiations in the Cortes were on the two items of the first line in the table.

Sources: Gelabert, La bolsa del rey, pp. 385-6; Lorenzo Sanz, Comercio de España, pp. 263-72; Martín Acosta, El dinero americano; Ulloa, La Hacienda Real, pp. 171-687; Zabala Aguirre, Las alcabalas, pp. 55-64.

contributions, which were stable but had no permanent legal status and had to be renewed by votes in the Cortes every few years. Below these are revenues that were neither politically nor economically stable.

In the ordinary revenues, the customs and profits from regulated monopolies were not controlled by the cities. Since the central government had no tax administration, and these taxes were collected at specific locations (for example, customs and salt mines), it was relatively easy to subcontract their collection to local entrepreneurs through tax farming. These revenues were under the direct control of the central government and thus did not benefit from the special protection that was given to taxes collected by the cities. They provided a base for debt funding, but that base was not as stable as the encabezamientos: these taxes were under the direct control of the central government, and they were subject to fluctuations in trade and general economic activity and to the risk of default by the tax farmer. Accordingly, they supported juros of lesser grade.

The extraordinary revenues, on the right-hand side of table 1, could not provide a good source of funding for the long-term public debt. Few juros were written on these revenues, at least in the sixteenth century, and they traded at a discount. Between 1560 and 1575, some juros were funded by the revenues of the Casa de la Contratación, a government agency that managed the silver revenues and was directly controlled by the Crown. ${ }^{31}$ Not surprisingly, these juros were traded at a significant discount. In this sense, there can be no meaningful relationship between silver revenues and the servicing of the debt.

Servicios (servicio ordinario, servicio extraordinario, and millones) were similar to the alcabalas. They were administered by the cities and their level was determined by centralized negotiations by the Cortes at the same that the alcabalas were being negotiated (see section V for 1575). However, the servicios, unlike the alcabalas, were voluntary contributions by the cities and had a temporary status that had to be renewed during these negotiations. They could not be used to service long-term bonds. The evolution over time of these different revenue streams is presented in figure 1 .

\section{III}

The short-term debt was in contracts, asientos, with Genoese bankers, who were the indispensable 'moneyed men' of Castile, the more so because there was no

\footnotetext{
${ }^{31}$ Ruiz Martín, 'Un expediente financiero', pp. 40-5.
} 


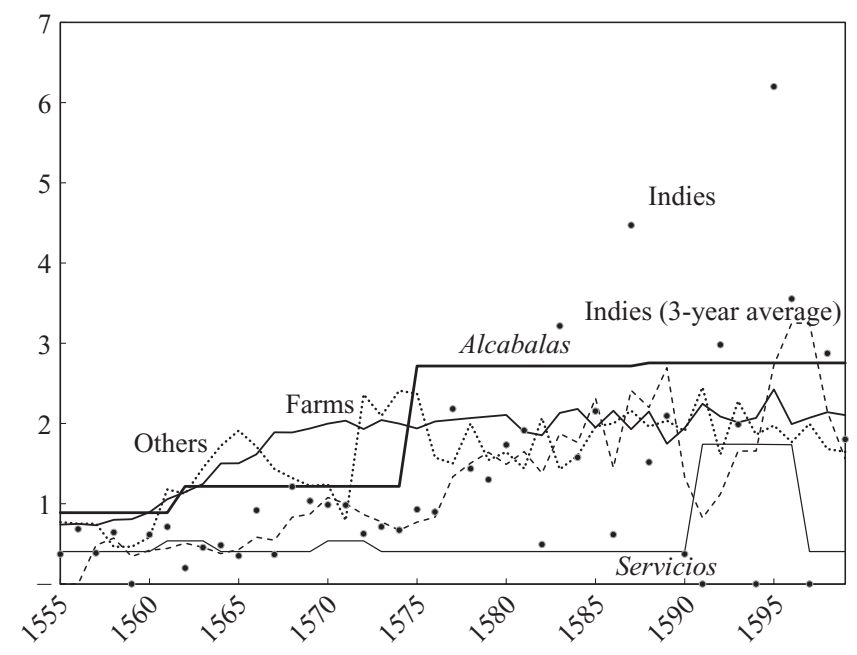

Figure 1. Revenues

Notes: Direct revenues from customs and monopolies are put together under 'Farms'. Note the high variability of the revenues from the Indies that are represented in actual numbers by points and in a three-year moving average by a curve. The millones are included in the servicios for the years 1591-6. Amounts are in millions of ducats (nominal).

Sources: As for tab. 1.

centralized financial market at that time. ${ }^{32}$ The asientos specified, in some but often not exhaustive detail, payment obligations between the bankers and the Crown (for example, date, place, currency, exchange rate, and interest rate). When the asientos included loans, the average maturity was about two years (though some contracts could last up to 10 years). When the exact dates for repayments were not fixed, the asiento often specified an interest rate. In the period between 1570 and 1575 , the usual rate was 12 per cent per annum. Contrary to some descriptions in the literature, the greater share of asientos was not written into loans to pay the army in Flanders. ${ }^{33}$ For example, in 1575 , less than 40 per cent of the total disbursements of asientos were in Flanders and about half were in Castile (with the rest in Italy and Besançon). The large share of domestic transactions illustrates the role of the Genoese bankers in capital markets within Castile (which was similar to the role later played by 'moneyed men' in England).

Some asientos were collateralized by juros (juros de caución and juros de resguardo). The collateral had two purposes: first, to serve as a collateral; second, in keeping with the overall fiscal policy setting, when spending shocks turned out to be more than transient, short-term loans could be converted into long-term loans. The lender could then sell the collateral instead of receiving cash. Such a sale should not be taken as a sign of failure from the Crown, but instead as part of an efficient overall policy. It was standard practice for the Crown, in a stable regime, to pay some asientos in juros.

\footnotetext{
${ }^{32}$ Charles V had a special relationship with the Fuggers. Under Philip II, from 1561 on, the main players were the Genoese bankers. They had the expertise to handle the complex transactions between Castile, the Netherlands, and Italy, and within Castile they operated through letters of exchange and other short-term contracts. For the importance of the 'moneyed men', see the next section.

${ }^{33}$ Conklin, 'Theory of sovereign debt', pp. 489-90.
} 
Under Charles V, the juros as collateral could be sold only if the Crown did not meet the terms of the asiento (juros de caución). Starting in 1561, following an initiative by the banker Juan Curiel de la Torre, some collaterals, called juros de resguardo, could be sold by the banker provided that he returned a similar juro later if the Crown met the payment schedule of the asiento. ${ }^{34}$ In this case, the service of the juro that had been sold would be deducted from the liability of the Crown. The system of the juros de resguardo enabled bankers to refinance asientos at a low interest rate. That system increased the banker's profitability. However, in the context of the fragmented juros market, the system introduced some confusion in the definition of the net debt of the Crown. It is therefore not surprising that the crisis of 1575 was, among other things, an 'information event' in which the Crown attempted to recalculate the liability it had accumulated since 1560, as actualized at the average rate of asientos (12 per cent). ${ }^{35}$

\section{IV}

Expenditure in Castile was driven by wars and was highly variable. The standard modern theory of public finance assumes a central government that minimizes tax distortions through tax smoothing. Any surprise in expenditure should be met with a frictionless adjustment of taxes to meet the intertemporal resource constraint. A textbook illustration is presented by parliamentary England in the eighteenth century (although it departed from that model during the Napoleonic Wars). ${ }^{36}$ The English method of debt financing became operational only after a long transition, between 1690 and 1740, that has been called a 'financial revolution'. ${ }^{37}$ Dickson has emphasized that, even after the completion of that transition, the English government could not issue large quantities of liabilities, both long- and short-term, without the close collaboration of institutions such as the Bank of England and the South Sea Company, and of skilled financiers. ${ }^{38}$

In Castile, as with all the governments at the time, the Crown had exclusive authority over expenditure. Cities, however, controlled the best taxes for servicing the debt and their contribution (encabezamiento) was set through collective bargaining in the Cortes. The Cortes could not meet independently like a modern Parliament. Instead, they had to be called by the Crown. No increase in the encabezamiento could be carried out without a meeting of the Cortes and the agreement of the cities. Negotiations with the cities would be protracted because of divergent political interests between the cities and the Crown and because of imperfect information between the Crown and the cities, between the Genoese

\footnotetext{
${ }^{34}$ Ruiz Martín, 'Las finanzas españolas'. During a brief period up to 1563, some asientos had as collateral juros por acomodar that were similar to juros de resguardo; Carlos Morales, Felipe II, pp. 93-4.

${ }^{35}$ In the modern theory of the debt contract (Townsend, 'Optimal contracts'), the creditor can get information on the debtor at some cost. The debt contract with a fixed interest rate is efficient because the creditor needs to get this information only in the case of default. Such an event can be called an 'information event'. In the case of Philip II, the debtor also had imperfect information on the creditors as they traded in collaterals. Hence, there was some efficiency in acquiring information about creditors only in the 'information event' of a suspension of payments. There is no formal analysis of this situation of double asymmetric information in debt contracts in the literature and it is beyond the scope of the present article.

${ }^{36}$ Barro, 'Government spending'.

${ }^{37}$ Dickson, Financial revolution.

${ }^{38}$ However, the interests that were represented by these institutions and people restricted the capability of the government to conduct efficient reductions of the interest rate on the public debt; Chamley, 'Interest reductions'.
} 


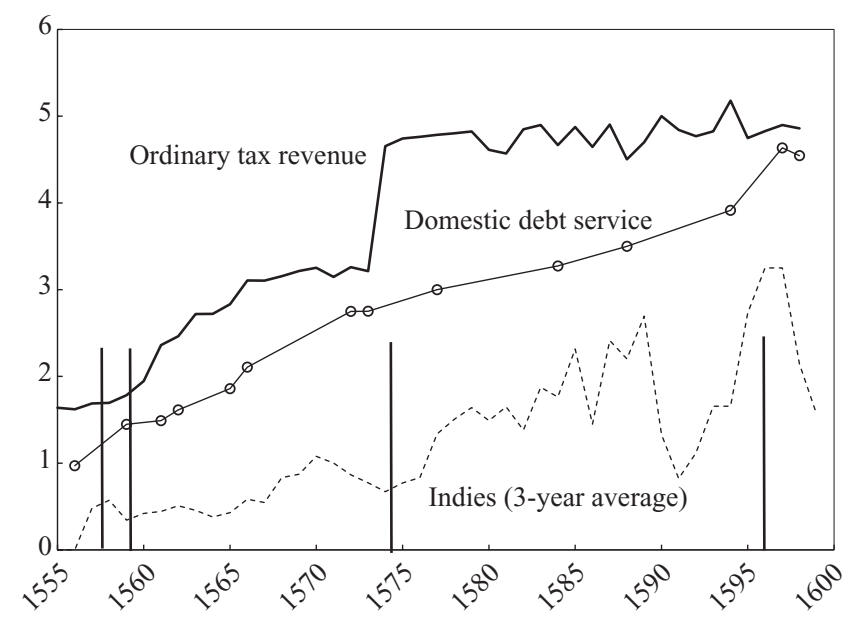

Figure 2. Debt service and ordinary taxes (in millions of ducats)

Notes: The amounts of the debt service are collected from different sources in the years that are represented by circles. The dates of the suspensions of payments are marked by vertical lines.

Sources: As for tab. 1.

bankers and the Crown/cities, and between the cities themselves. The problem of asymmetric information between the Crown and the realm was well known in all feudal countries where the sovereign faced a constraint of 'evident necessity' and had to justify taxation (in men or money) for wars. A contribution to the solution of the information problem was found in the twelfth century in the Cortes of Aragon, ${ }^{39}$ and in the thirteenth century in England. ${ }^{40}$

The Cortes did not have the power completely to oppose a tax increase, but they could impose a cost on the Crown by reducing the amount of the tax increase, or delay its implementation for a few years, as in the crisis of 1573-7. Revenues from the encabezamiento and other ordinary taxes provided a ceiling on the service of the juros that were of the highest grade. As long as the ceiling was not reached, the Crown could issue more juros. In that regime, the Crown used the short-term unfunded asientos, which had a rate about twice the rate of the funded juros (about 12 per cent against 6 per cent), in order to absorb transitory shocks and fund transfers abroad. However, there was no significant accumulation of short-term debt.

Such a regime was in place in the years that followed the settlements of 1560 and 1577. It is illustrated in figure 2 by the evolution of the service of the juros (called the situado), and the level of ordinary revenues, as described in table 1 . These revenues are the sum of the encabezamientos that were negotiated in the Cortes and of the farmed revenues (including monopolies), which grew between 1560 and 1570 (figure 1), but seem to have reached their capacity in 1573.

When the service of long-term debt neared the ceiling of the ordinary revenues, as in the early 1570 s and the late 1590s (figure 2), refinancing the asientos through

\footnotetext{
${ }^{39}$ O'Callaghan, Cortes.

${ }^{40}$ For an analysis of the role of asymmetric information in Magna Carta (1215), see Green, 'Emergence'.
} 
juros became more difficult and the Crown initiated negotiations with the cities. ${ }^{41}$ During this phase, asientos accumulated. Before the suspensions of payments in 1557,1575 , and 1596, the amounts of outstanding asientos, gross of the collaterals, were 7.5, 15, and 7 million ducats, respectively. Each of these crises is represented by a vertical line. The first two, in 1557 and 1560, are actually two steps of the same crisis. At the end of each crisis, all the outstanding asientos were converted into juros.

Each crisis formally began with a suspension of payments on the short-term debt to the foreign bankers. (In 1575, this came as a surprise to the bankers.) In a situation of asymmetric information, a suspension of payments may be an additional argument for the Crown to convince the cities of the 'evident necessity' of more funds. In 1575, the suspension of payments also provided an opportunity to review dealings in the collaterals of the asientos.

A crisis after a suspension of payments lasted until the Crown settled first with the cities, and then with the bankers in a final document called the Medio General. (There was no Medio General in the resolution of the 1560 crisis.) The bankers may have taken a debt reduction, but the empirical evidence about the exact amount of debt reduction is not clear at this point. The cities accepted higher taxes in the settlements of 1560 and 1577. In 1598, taxes were not increased but the interest rate was reduced on some juros. However, that settlement should be viewed as a prelude to the next negotiations of 1607, after the death of Philip II, as the temporary settlement of 1558 preceded that of 1560. A key feature of each settlement was the conversion of all the asientos, net of any debt reduction, into long-term juros. That feature has been neglected in the literature but reinforces our interpretation of the debt policy of the kingdom of Castile. We now analyse the three crises in more detail.

The events of 1557-60 must be considered as one single, long financial crisis. At the beginning of his reign in 1556, Philip II inherited from his father, Charles V, a debt of 7.5 million ducats in asientos. ${ }^{42} \mathrm{He}$ ordered a review of the accounts and began negotiations with some bankers to refinance asientos into juros. However, the service of the debt was reaching the total amount of ordinary revenues, leaving no room for more juros (figure 2). On 17 April 1557, Philip II declared his first suspension of payments.

The decree was not intended to repudiate the asientos, even partially. It declared a conversion of some asientos into juros at 5 per cent-the bankers could sell these on the market. ${ }^{43}$ That conversion did not apply to the Fuggers who were, at the

\footnotetext{
${ }^{41}$ Because of the decentralization of the juros, their service in some towns may be up to the revenue constraint before the aggregate service reaches the aggregate ordinary revenues (fig. 3 ).

${ }^{42}$ Carlos Morales, Felipe II, p. 38. See also a report from March 1557 (AGS, Estado, leg. 121, fo. 61) that is referenced by Toboso Sánchez, La deuda pública, p. 115. The computation of the short-term debt is always approximate. Asientos were not traded in a market and the indebtedness on a particular contract at a particular point of time depends on assumptions about the interest rates and the exchange rates. There is no such thing as 'the interest rate', in today's economies and a fortiori, in the fragmented capital market of Castile.

${ }^{43}$ Ruiz Martín, 'Un expediente financiero', p. 11, reports that for the year $1552,47 \%$ of the juros were redeemable. In that type, $47.6 \%$ paid a rate of $7.14 \%, 5.2 \%$ a rate of $5.5 \%$ and $30 \%$ a rate of $5 \%$. The remaining $16 \%$ paid other rates.
} 
time, some of the main creditors, and it did not address the main problem, which was the ceiling on ordinary revenues. The second part of the policy was the promulgation on 30 April 1558, by the regent in Castile, the princess Doña Juana, of a new tax on wool exports. New customs were also created between Portugal and Castile on 30 January $1559 .{ }^{44}$

Genoese bankers had accepted the juros at 5 per cent in order to settle the negotiations. However, juros at 7.14 per cent were obviously selling faster than juros at 5 per cent. The bankers therefore proposed to undertake the conversion into juros at a rate between 7.14 and 10 per cent in the following years, while they granted new asientos. That policy, which was probably viewed as a stopgap, was initiated by Nicolao de Grimaldo in May 1558 and followed by all other bankers between 1558 and 1560 .

When Philip II returned from Flanders to Castile for the first time as king on 8 September 1559, he intended to put the finances of the Crown in order. He summoned the Cortes in Toledo and ordered a general review of the budget. The stock of juros was 21.7 million ducats, with an interest service of 1.5 million. ${ }^{45}$ The debt in asientos was 4.5 million, as the 1557 decree had refinanced only some of the short-term debt. ${ }^{46}$ Negotiations would last for the entire year. On 14 November 1560, the king declared his second suspension of payment on the asientos.

The conversion from asientos to juros was made possible because the 1559-60 Cortes agreed to increase the alcabalas by 37 per cent, effective from 1562. All asientos were then converted into juros. In the current state of knowledge, it is doubtful that the first suspension of payments of Philip II generated any default on the asientos. There was no Medio General after the suspensions of payments of 1557-60. After the settlements, which were made separately between individual bankers and the Crown, the signing of new asientos resumed rapidly. ${ }^{47}$ From 1562 onwards, juros de resguardo would be issued on the new alcabalas.

The crisis of 1573-7 was a pivotal moment for the finances of Philip II. As in other crises, the interaction between the Crown and the cities should take centre stage, and that power game began well before the suspension of payments in 1575.48

Following the Dutch revolt in the late 1560s, military expenditures increased rapidly during the early 1570s, both in Flanders and on the sea (the Battle of Lepanto occurred in 1571). As revenues from the Indies had decreased during this period (see figure 1), the deficit increased. The encabezamiento had been fixed, in nominal terms, in 1562. During the 1560s, the Crown increased the ordinary revenues through higher rates on existing taxes and through the introduction of

\footnotetext{
${ }^{44}$ Ulloa, La Hacienda Real, p. 253.

${ }^{45}$ Pulido Bueno, La Corte, p. 76.

${ }^{46}$ Neri, Uomini d'affari, p. 83.

${ }^{47}$ Some asientos were written with non-tradable collaterals (juros de caución) at $7.14 \%(14,000$ al millar). At the same time, for one million ducats of the pre-1560 debt that had been paid in juros at $5 \%$ in the 1560 decree, the rate was increased to $7.14 \%$. The episode illustrates that the amount of debt reduction was raised in later negotiations with the bankers. One cannot take the terms of a Medio General for an accurate estimation of the actual debt reduction. The gradual conversion of juros on the Casa de la Contratación into juros of higher grade was implemented through contract clauses in new asientos; Ulloa, La Hacienda Real, p. 763.

${ }^{48}$ For the historical descriptions, see reference works: Fortea Pérez, Monarquía y Cortes, pp. 42-88; idem, ‘'Impuestos o servicios?'.
} 
new taxes and new regulated monopolies. ${ }^{49}$ Figure 2 illustrates the rise of these revenues. Their growth stopped in the early 1570 s for two reasons. First, there were limited opportunities for an increase in the tax base, or in the existing rates. Second, most of these revenues were related to trade, which suffered after the beginning of the Dutch revolt. In any case, these ordinary revenues were farmed out and could not support juros at the lowest rate, of the same type as those that were funded by the encabezamientos.

It was obvious that the service of the debt was absorbing most of the Crown's ordinary revenues (figure 2). As juros were issued against revenues from cities, the local constraints on these revenues became effective in some cities; for example, in Burgos and Murcia (figure 3).

The situation called for an increase in tax revenues for the funding of the public debt, and therefore it was necessary for the Cortes to meet. The crisis developed in two phases. First, from 1573 to 1575, the Crown made a number of attempts to obtain more revenues from the cities. When that process failed, the Crown promulgated through a decree, in September 1575, a stop on the short-term debt payments, and conducted negotiations on two fronts with the cities and the bankers. That second phase lasted until the final settlement, first with the cities at the end of November 1577, and immediately afterwards with the bankers in the Medio General. ${ }^{50}$

The crisis began in April 1573, when Philip II summoned the Cortes and, as in previous negotiations in 1559 , proposed a 30 -year plan to get rid of the public debt (desempeño): ${ }^{51}$ higher taxes would generate a surplus for 20 years and, for the last 10 years, the burden would be reduced to finish off the remaining debt. Initially, the cities accepted the general idea of the plan, but they continued to negotiate through the Cortes. No stable agreement could be achieved without the formal approval of all the cities.

While negotiations dragged on, Philip II tried a second plan in December 1573: a new flour tax would be created that would be applicable without exemption. In this way, the increased tax burden would be evenly distributed throughout the Spanish realm. The flour tax, even at a low rate, would have provided a huge extension of the tax base..$^{52}$ The cities strongly opposed the tax and insisted instead on a commitment to a permanent reduction of taxation in the future, and to a stop on the sales of offices..$^{53}$ The Cortes were suspended at the end of 1573 to enable the delegates to return to their cities for consultation. Heated discussions delayed the resumption of the Cortes until June 1574.

Each delegate came back with special ad hoc demands. As a further complication, taxation of the clergy required a papal decree. During the summer of 1574, other issues were discussed, such as the formal transfer of the juros in quotas to the cities, which would then be free to choose how to service or redeem them, or the

\footnotetext{
${ }^{49}$ In 1559, the customs tax base was extended. The import tax rate from the Americas was raised in 1566. Additional taxes on wool exports were introduced in 1558 and 1566. After 1564, a regulated monopoly was introduced to increase the revenues from the salt tax up to 0.2 million ducats $(1 / 6$ of the alcabalas). In 1563, another monopoly was introduced on the production of mercury.

${ }^{50}$ Lovett, 'Castilian bankruptcy', p. 910; idem, 'General Settlement', p. 19.

${ }^{51}$ Fortea Pérez, Monarquía y Cortes, p. 45.

${ }^{52}$ The tax could have yielded between three and four million ducats; ibid., pp. 418-20.

${ }^{53}$ Furthermore, they were sceptical regarding the Crown's commitment to a budget surplus-a claim no more credible in the sixteenth century than it would be in the twenty-first.
} 
Burgos

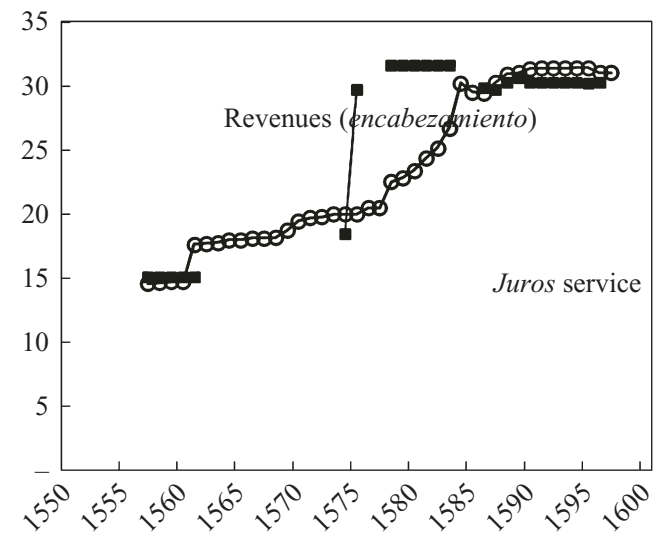

Murcia

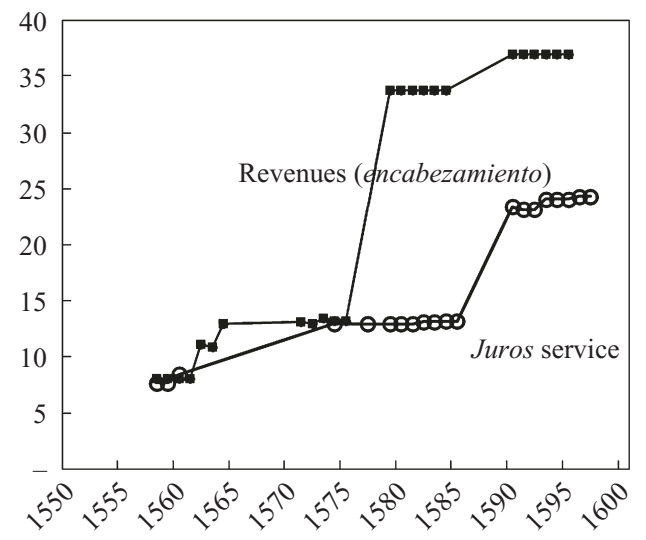

\section{Cádiz}

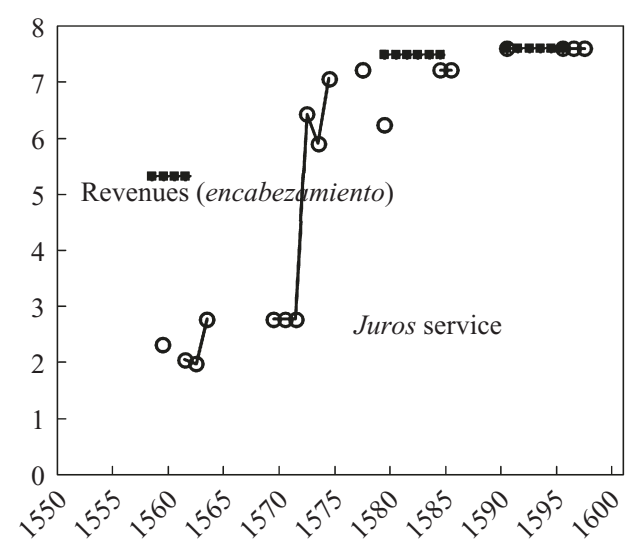

Figure 3. Service of juros and funding taxes (encabezamiento) for Burgos, the region of Murcia, and Cadiz (in thousands of ducats)

Sources: Furos service: AHN, Consejos Juros, leg. 1777. Encabezamiento: Zabala Aguirre, Las alcabalas, p. 60; Archivo General de Simancas, Valladolid (hereafter AGS), Contaduría Mayor de Cuentas $2^{\circ}$ época, leg. 173.

redistribution of the tax burden between the cities. These were particularly concerned with the unfunded debt of the asientos and the role of the Genoese bankers. ${ }^{54}$ The strong popular sentiment against asentistas, similar to the reaction today against banks, was used in the following year by Philip II in his decree by which payments to the bankers were suspended. Unable to find an agreement, the Crown changed strategy.

The Crown then abandoned the pretence of the desempeño, although the cities continued to insist on it, ${ }^{55}$ and invoked instead the large increase in war expenditure, and the imbalance between the encabezamiento at its 1562 level compared to

\footnotetext{
${ }^{54}$ The city of Salamanca instructed its delegates to reject the redemption plan unless a commitment was made to throw out of the kingdom all foreigners who dealt with asientos; Fortea Pérez, Monarquia y Cortes, p. 62.

${ }^{55}$ Ibid., p. 73.
} 
the increase in other tax revenues. During these protracted negotiations, the gap between the ordinary revenues and the interest service of the juros continued to close.

On 20 September 1574, Philip II tripled the encabezamiento general from 1.2 to 3.7 million. ${ }^{56}$ The policy was extraordinary in its timing and amount. All previous levels of the encabezamientos in 1536, 1547, 1552, and 1562 had been determined during meetings of the Cortes. Without the cities' agreement the tax could not have been expected to be stable. Legally, it was just another extraordinary levy. Despite Philip II's efforts to employ a special task force of 'administrators, taxfarmers and public inspectors', ${ }^{57}$ it is doubtful that the decree of 1574 was actually implemented. ${ }^{58}$ Why Philip II insisted on such a large increase is not clear. Obviously, a smaller increase would have provided sufficient room for greater debt service-as was the case for another 10 years after the final settlement of 1577 . Since the encabezamiento had not changed since 1562 with a fall in real value of 12 per cent, and since the cities eventually accepted, in 1577, a doubling of the encabezamiento, it is clear that if the issue had been a liquidity crisis the Crown could have obtained agreement on a modest tax increase. However, the Crown had decided from 1573 onwards to obtain a large increase of revenues and it was engaged in a power play with the cities.

Philip II signed a decree that put a stop to payments to the Genoese bankers on 1 September 1575, following the arrival of the fleet on 11 August $1575 .{ }^{59}$ During 1574 , new asientos had been issued to an amount of 6.219 million ducats, close to the record level of 1572 (6.248 million ducats). That total included 2.658 million ducats to be paid in Flanders, about 3 million ducats in Castile, and the rest in Italy. ${ }^{60} \mathrm{~A}$ complete list of all the asientos signed between January and the suspension of payments is presented in table 2 .

During the eight months before the suspension in September 1575, Genoese bankers signed new asientos for 4.8 million ducats, the highest amount within such a short interval. Between March and July, Nicolao de Grimaldo made the most important loans, by far, for a total amount of 1.9 million ducats. The first one (1.3 million ducats) was provided for disbursements during 1575 and repayments by the king during the same year in three tranches after each four-month period ( 37.5 per cent for each of the first two). The short maturity of that loan shows that Grimaldo was prudent. All bankers must have been cognizant of the financial situation of the Crown. As moneyed men, they had close ties with the government in Castile. Some may even have participated in financial committees of the government. The cities would resist an increase in the alcabalas, but the bankers were confident that there was a base for higher taxes and many of the asientos during the spring of 1575 were written on the promise of higher alcabalas from 1575 onwards. The situation is easy to picture in the context of the current lending crisis in

\footnotetext{
${ }^{56}$ It was expected that a large part of the increase would come from an extension of the tax base to include bread, wine, fruit, and agricultural products that had so far been exempted de facto, and would now be taxed at about $4 \%$; ibid., p. 71 .

${ }^{57}$ Jago, 'Philip II', p. 31; Hernández Esteve, Establecimiento de la partida doble, pp. 164-5.

${ }_{58}$ Thompson, 'Castile', p. 169, claims that revenues could even have decreased, in reaction to the tax jump.

${ }^{59}$ Revenues from the Indies in 1575 were 0.9 million ducats, about a $50 \%$ increase on the average of the previous three years.

${ }^{60}$ AGS, Contadurías Generales, leg. 86.
} 


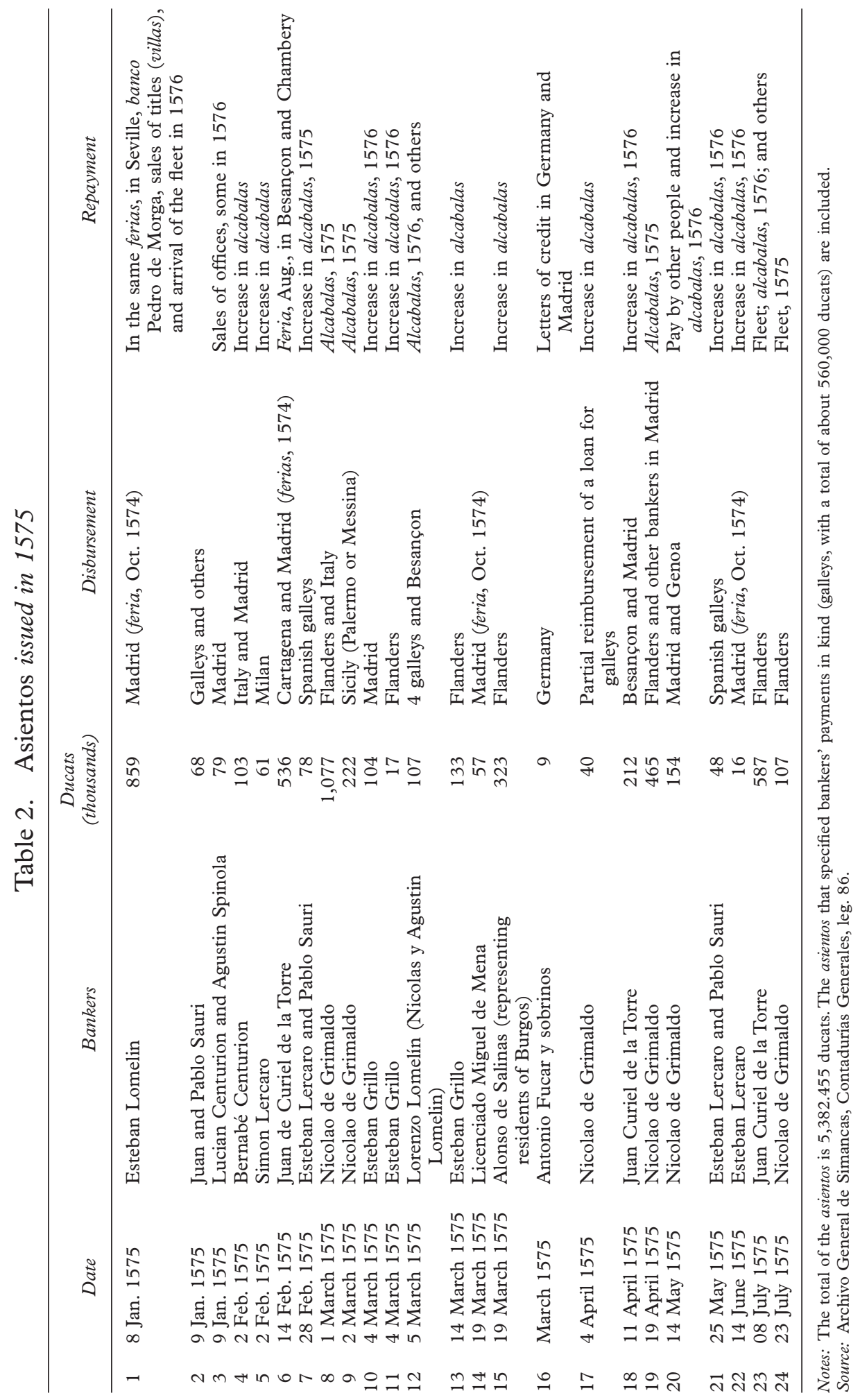


Greece. The bankers knew that the situation was risky, but they would not have made these record loans in the spring of 1575 if they had anticipated the suspension in September.

After Philip II had given a clear signal in the decree both of his need for more revenues and of his toughness towards the resented asentistas, he again called the Cortes to begin negotiations in November. ${ }^{61}$ The business of the Cortes was to readjust three types of taxes, the encabezamiento of the alcabalas, the ordinary service, and the extraordinary service. The usual sequence was to agree on the servicio ordinario and the servicio extraordinario first, and then to bargain on the main item, the encabezamiento. This time, however, the Cortes, in order to increase their bargaining power, reversed the order and requested first a renegotiation of the 1574 decree (which had tripled the encabezamiento), before voting on the two services.

Negotiations were very slow. Why did Philip II reject his impatient aides' facile advice to use force? We think that he had at least two motives. First, he knew that he had to play a political game with the cities that represented the realm, and that the game was likely to be repeated. Second, Philip II was rational and he probably anticipated the eventual consequences of the suspension of payments for the credit market and the trading activities of the cities. We discuss this issue briefly below.

It took almost a year, until August 1576, to agree to move the servicio ordinario up the agenda, before the encabezamiento. Then the negotiations dragged on for more than another year, until 29 October 1577. In previous adjustments of the encabezamiento, increases had been roughly proportional across cities. For the contract of 1577, however, the shares of some cities jumped up: Seville from 10.2 per cent in 1557 to 17.5 per cent in 1577, and Toledo from 5.8 to 7.6 per cent, while Granada's share dropped from 9.2 to 5 per cent. ${ }^{62}$ After the agreement on the encabezamiento, voting on the servicio extraordinario was accelerated and a final agreement was reached in the following month.

For the Crown and also for the Genoese bankers, the suspension of payments did not mean a default to the bankers. Before the end of the year, the Crown set the principle that all the debt would be paid at 12 per cent. The question was, which debt? Recent literature has emphasized the role of bankruptcy as the outcome of an efficient loan contract that saves the cost of information that must be acquired by the lender. ${ }^{63}$ In 1575 , one could argue that the need for more information was on the side of the borrower, Philip II. A simple theoretical model that captures the complexity of the network of asientos and their related sidecontracts is beyond the scope of this article. Because of these intertwined sidecontracts, especially on the collaterals, there was a dire need for a review of all the contracts. That review had to be comprehensive because of the connections between loans and collaterals in juros, and in order to achieve an orderly conversion of all short-term asientos into long-term juros.

Because the bankers substituted some of the asiento's collaterals (juros de resguardo) with juros of lower grade, the liabilities of the different parties were difficult to assess. This justified the Crown's creation of a commission to review all asientos that had been signed since 14 November 1560: 296 contracts with 66

\footnotetext{
${ }^{61}$ Fortea Pérez, Monarquía y Cortes, p. 248.

${ }^{62}$ Zabala Aguirre, Las alcabalas, pp. 55-98, and esp. tab. 9, p. 64.

${ }^{63}$ Townsend, 'Optimal contracts'.
} 
people (35 with Nicolao de Grimaldo, 34 with Lucian Centurion, 32 with Lorenzo Spinola, and so on). The balance of each active asiento was computed by bringing past payments up to the current date with the standard interest rate of 12 per cent. ${ }^{64}$

The Crown and the bankers agreed on the amount of 15.2 million ducats in the early spring of 1577 , as stated in the final settlement. The larger part of the debt was not in unpaid arrears, but in repayments that were contractually scheduled for the future. We have examined all the asientos that were initiated between 1570 and 1575 (and some before 1570), and extracted those that specify contracts after 1575. The total amount of the payments scheduled after 1575 exceeded 12 million ducats. Given the average maturity of these remaining liabilities, an approximate estimate of the present value of the scheduled repayments is about 10 million ducats. Arrears would then represent about 5 million ducats. ${ }^{65}$

The terms of the final settlement between the Crown and the bankers had been set in March 1577, but the signing of the settlement had to wait, with no significant change, for another nine months until the end of the negotiations in the Cortes. The long delay between the agreement with the bankers in March 1577 and the signature in December after the closing of the Cortes is additional evidence that the difficult negotiations between the Crown and the cities was the major cause of the suspension of payments. Immediately after the agreement in the Cortes, the Medio General was signed between the Crown and the bankers on 5 December 1577.

A powerful incentive for the cities to settle was the adverse impact of the crisis on the domestic credit market and trade. We have seen that a large fraction of the asientos was internal to Castile. Like the moneyed men of eighteenth-century England, the Rothschilds in the Napoleonic era, or modern bankers today, the main role of Genoese bankers was to underwrite loans, and not to lend on their own funds. It is very likely that the funds for the asientos that were disbursed in Castile came from Castile.

The suspension of payments on the asientos also put a stop to the main fairs at Medina del Campo. They eventually resumed, in 1578, but they had lost their pre-eminence in the network of commercial fairs and never regained it.

In the settlement, the debt of 15.2 million ducats was divided into two parts: 10.4 and 4.8 million ducats, respectively. ${ }^{66}$ The first part, 10.4 million ducats, corresponded to juros: 8 million ducats were paid by juros de resguardo that had been written at 7.14 per cent and were reduced to 5 per cent. The remaining 2.4 million ducats corresponded to juros written on the Casa de la Contratación and were accounted for at their market value, 55 per cent of the face value. The second part of the debt, 4.8 million ducats, was subdivided into two parts. Two-thirds were paid by juros on salt at the rate of 3.3 per cent $(30,000$ al millar). For the remaining third, the holders of asientos were compensated by the monetary equivalent of property rights on individuals (vasallos) and of the granting of legal powers (jurisdicciones) on some church territories that had been allowed by a bull

\footnotetext{
${ }^{64}$ Carlos Morales, Felipe II, p. 164.

${ }^{65}$ The existence of arrears is also confirmed by the terms of some asientos signed before 1575 that included clauses for the payments of arrears.

${ }^{66}$ We use rounded numbers. The Medio General specified exact numbers that can be found in the literature; Carlos Morales, Felipe II, p. 178. Here, the exact amount is $15,184,464$ ducats.
} 
of Gregory XIII on 6 April 1574. The values of these effects were computed with discount rates at 6.5 and 2.35 per cent $(16,000$ and 42,500 al millar) depending where they were situated in Castile.

We emphasized in the introduction that some details of the settlement with the bankers are critical for its interpretation and for the evaluation of any debt reduction. As shown in the description of the juros, the reduction of the interest rate from 7 to 5 per cent could not be a default, contrary to previous literature cited above. We also noted previously that the reference to a unique interest rate on juros would be ahistorical because of the fragmented credit market. The reduction of the interest on old juros through the crecimiento necessarily implied the coexistence of juros with different interest rates that had different expectations of redemption and were arbitraged by the market. The actual interest rate on juros depended on the marketability of new juros. Ruiz Martin has provided some evidence of juros at 5 per cent that traded during the period of 1570 to 1575 for 17,000 al millar, which is equivalent to a rate of 5.88 per cent. ${ }^{67}$ In the archives of Simancas, there are numerous documents that show sales of juros at 5 per cent, or even lower (see below), throughout the 1570 s. $^{68}$

After the signing of the Medio General, the Crown issued a number of orders to specify the details of the payments. Under some special provisions, bankers could be in charge of applying the crecimiento to some juros and recovering the proceedings from reimbursements for asientos.

With regard to the second part of the debt (4.8 million ducats), the terms of the Medio General do not enable us to have a precise evaluation of the terms of the settlement. The rate of the juros written on the salt tax was equal to 3.33 per cent (30,000 al millar). There is some indication that the 'market rate' of such juros was less than 5 per cent, but this issue is yet to be researched. If we apply the same discount to the other third of the debt of 4.8 million ducats, the upper bound for the reduction of the 1575 short-term debt is equal to 1.6 million, that is, 11 per cent of the total. ${ }^{69}$

In 1588, the disaster of the Great Armada was apparent to all, without asymmetric information on the revenue needs of the Crown (as mentioned in the record of the 1589 Cortes). Although the debt service was far below the ordinary revenues (figure 2), the cities quickly granted a special tax. Patriotism trumped tax smoothing. It was levied like the alcabalas under the encabezamiento, but the cities insisted on the specific purpose of the tax, which was given a different name, the servicio de millones, and the payment was limited to a term of six years.

When the millones ended in 1596, as scheduled, the service of the long-term debt, which had gradually increased since the previous settlement, had reached the level of the funding revenues (figure 2). The Crown first attempted to renew the millones, under a different name (the cuentos).$^{70}$ After no majority agreement could be reached in the Cortes, the government abandoned the project, leaving its implementation to the next king, Philip III.

\footnotetext{
${ }^{67}$ Ruiz Martín, 'Las finanzas españolas'.

${ }^{68}$ For more details, see the working paper and data at http://people.bu.edu/chamley/papers/documents/ juros 1572.pdf.

${ }^{69}$ Some decrees after 1577 compensated bankers for losses that they had incurred in the settlement of 1577 .

${ }^{70}$ Fortea Pérez, Monarquía y Cortes, p. 155.
} 
As in the previous crisis of 1575 , the crisis of 1596 was not caused by a liquidity problem but by the refusal of the cities to raise taxes. This imposed a ceiling on the domestic debt. ${ }^{71}$ If the ratio between the service of the long-term debt and the funding revenues had been the same as in the early 1590s, no crisis would have occurred.

The decree was published on 29 November 1596, again to the surprise of the asentistas and to the satisfaction of the cities. ${ }^{72}$ The total debt recognized by the king was 7 million ducats. ${ }^{73}$ Unlike 1575, the suspension of payments to the Genoese bankers was not used as a device to increase ordinary revenues. Economic activity had stopped growing since the 1580s, which explains the fact that the ordinary revenues were stationary (figure 1). The Crown and the Cortes probably felt that higher domestic taxation would be difficult to enforce. On the other hand, interest rates on juros had decreased since the previous financial crisis. The conversion of asientos into juros was achieved by a combination of interest reduction and issuance of juros on some available ordinary revenues that were less stable. ${ }^{74}$ We have described previously how interest reductions through crecimientos were not defaults.

\section{VI}

The fiscal system of Philip II was much more ingenious than previous literature suggests. We have shown how it was adapted to the constraints of its time and that its evaluation according to the standards of twenty-first-century economies can lead to serious misinterpretation. The main achievement of Philip II's government was to mobilize large financial resources by transforming the apparent weakness of the kingdom's fragmented political and economic institutions into a strength. This allowed the king to build the domestic public debt to something akin to that of modern magnitude.

Philip II's suspensions of payments were not caused by liquidity problems but were part of the overall efficiency of the system. Thompson, who is an exception in the literature, was the first to express that point of view. ${ }^{75}$ To apply the expression 'serial defaulter' to Philip II is thus an error of interpretation. Furthermore, evidence about the actual dealings between the government (Tesoro General) and the Genoese bankers seems to indicate that a significant part of alleged reductions were transactions at prices not far from market values. An exact computation of the actual debt reduction would require the examination of documents in the years after the crisis resolutions and is thus beyond the scope of the present paper.

Many aspects of the finances of Castile under Philip II, large and small, are yet to be examined. The archives in Simancas contain a large amount of information that will be useful for this task. In future work, the fiscal system of Philip II should

\footnotetext{
${ }^{71}$ The shortfall of the millones ( 1.33 million ducats) was compensated for by the high silver revenues, 6.2 million and 3.5 million ducats in 1595 and 1596, compared to an average of 1.225 million for 1591-4 (fig. 1).

${ }^{72}$ Ulloa, La Hacienda Real, p. 820.

${ }^{73}$ Sanz Ayán, 'Procedimientos', p. 30, gives a figure of 7 million ducats, while Ulloa, La Hacienda Real, p. 823, gives a figure of $7,831,251$ ducats.

${ }^{74}$ See above, n. 67.

75 "This very periodicity [of the fiscal crises] suggests that rather than the manifestation of "crisis" these "bankruptcies" were an integral part of the financial system of the Monarchy. The term "bankruptcy" can be misleading'; Thompson, 'Castile', p. 160.
} 


\section{also be integrated with the history of political institutions and studies by historians who highlight the high degree of autonomy of the cities in the kingdom of Castile.}

\section{Footnote references}

Álvarez-Nogal, C. and Prados de la Escosura, L., 'The decline of Spain, 1500-1850: conjectural estimates', European Review of Economic History, 11 (2007), pp. 319-66.

Andrés Díaz, R. d., El último decenio del reinado de Isabel I a través de la tesorería de Alonso de Morales (1495-1504) (Valladolid, 2003).

Artola, M., La Hacienda del Antiguo Régimen (Madrid, 1982).

Barro, R. J., 'Government spending, interest rates, prices, and budget deficits in the United Kingdom, 1701-1918', fournal of Monetary Economics, 20 (1987), pp. 221-47.

Barthe Porcel, J., Los juros (desde el juro de heredat hasta la desparición de los cargos de justicia, siglos XIII al XX), Anales Universidad (Murcia, 1949).

Bean, R., 'War and the birth of the nation state', fournal of Economic History, 33 (1973), pp. $203-21$.

van Bochove, C., 'Intermediaries and the secondary market for public debt in the Dutch Republic', Utrecht Univ. working paper (2012).

Brewer, J., The sinews of power (Cambridge, 1988).

Carlos Morales, C. J. d., Felipe II: el imperio en bancarrota. La Hacienda Real de Castilla y los negocios financieros del rey Prudente (Madrid, 2008).

Chamley, C., 'Interest reductions in the politico-financial nexus of 18th century England', fournal of Economic History, 71 (2011), pp. 555-89.

Conklin, J., 'The theory of sovereign debt and Spain under Philip II', fournal of Political Economy, 106 (1998), pp. 483-514.

Dickson, P. G. M., The financial revolution in England: a study in the development of public credit 1688-1756 (1967).

Drelichman, M. and Voth, H.-J., 'The sustainable debts of Philip II: a reconstruction of Spain's fiscal position, 1566-1596', fournal of Economic History, 70 (2010), pp. 814-43.

Elliott, J. H., 'A Europe of composite monarchies', Past and Present, 137 (1992), pp. 48-71.

Fortea Pérez, J. I., Monarquía y Cortes en la Corona de Castill: las ciudades ante la política fiscal de Felipe II (Salamanca, 1990).

Fortea Pérez, J. I., ‘¿Impuestos o servicios?: Las Cortes de Castilla y la política fiscal de Felipe II (1573-1598)', in J. I. Fortea Pérez, ed., Las Cortes de Castilla y León bajo los Austrias: una interpretación (Valladolid, 2008), pp. 161-89.

Gelabert, J. E., La bolsa del rey: rey, reino y fisco en Castilla (1598-1648) (Barcelona, 1997).

Gelderblom, O. and Jonker, J., 'Public finance and economic growth: the case of Holland in the seventeenth century', Fournal of Economic History, 71 (2011), pp. 1-39.

Grafe, R., Distant tyranny: markets, power, and backwardness in Spain, 1650-1800 (Princeton, N.J., 2012).

Green, E. J., 'On the emergence of parliamentary government: the role of private information', Quarterly Review, 17 (1993), pp. 2-16.

Hernández Esteve, E., Establecimiento de la partida doble en las cuentas centrales de la Real Hacienda de Castilla (1952), vol. I (Madrid, 1986).

Hopkins, K., 'Rome, taxes, rents and trade', in W. Scheidel and S. von Reden, eds., The ancient economy (1995), pp. 190-230.

Irigoin, A. and Grafe, R., 'Bargaining for absolutism: a Spanish path to nation-state and empire building', Hispanic American Historical Review, 88 (2008), pp. 173-209.

Jago, C., 'Philip II and the Cortes of Castile: the case of the Cortes of 1576', Past and Present, 109 (1985), pp. 24-43.

Lorenzo Sanz, E., Comercio de España con América en la época de Felipe II (Valladolid, 1979).

Lovett, A., 'The Castilian bankruptcy of 1575', Historical fournal, 23 (1980), pp. 899-911.

Lovett, A., 'The General Settlement of 1577: an aspect of Spanish finance in the early modern period', Historical Fournal, 25 (1982), pp. 1-22.

Martín Acosta, M. E., El dinero americano y la política del Imperio (Madrid, 1992).

Neri, E., Uomini d'affari e di governo tra Genova e Madrid (secoli XVI e XVII) (Milán, 1989).

O’Callaghan, J. F., The Cortes of Castile-León, 1188-1350 (Philadelphia, Pa., 1989).

Pérez-Prendes, J. and Torres López, M., Los juros: aportación documental para una historia de la deuda pública en España (Madrid, 1963). 
Pezzolo, L., 'Government debts and credit markets in Renaissance Italy', in F. Piola Caselli, ed., Government debts and financial markets in Europe (2008), pp. 17-33.

Pulido Bueno, I., La Corte, las Cortes y los mercaderes: politica imperial y desempeño de la Hacienda Real en la España de los Austrias (Huelva, 2002).

Reinhart, C. M. and Rogoff, K., This time is different: eight centuries of financial folly (2009).

Ruiz Martín, F., 'Un expediente financiero entre 1560 y 1575: La Hacienda de Felipe II y la Casa de la Contratación de Sevilla', Moneda y Crédito, 92 (1965), pp. 3-58.

Ruiz Martín, F., 'Las finanzas españolas durante el reinado de Felipe II', Cuadernos de Historia. Anexos de la Revista 'Hispania 2 Extra', 2 (1968), pp. 109-73.

Sanz Ayán, C., 'Procedimientos de la Monarquía ante la suspensión de pagos de 1596', in C. Sanz Ayán, ed., Estado, monarquía y finanzas: estudios de historia financiera en tiempos de los Austrias (Madrid, 2004), pp. 21-37.

Thompson, I. A. A., 'Castile: polity, fiscality, and fiscal crisis', in P. T. Hoffman and K. Norberg, eds., Fiscal crisis, liberty, and representative government, 1450-1789 (Stanford, Calif., 1994), pp. 140-81.

Toboso Sánchez, P., La deuda pública castellana durante el Antiguo Régimen (Furos) y su liquidación en el siglo XIX (Madrid, 1987).

Townsend, R. M., 'Optimal contracts and competitive markets with costly state verification', fournal of Economic Theory, 21 (1979), pp. 265-93.

Tracy, J. D., A financial revolution in the Habsburg Netherlands: renten and renteniers in the County of Holland, 1515-1565 (Berkeley, Calif., 1985).

Tracy, J. D., Emperor Charles V, impresario of war: campaign strategy, international finance, and domestic politics (Cambridge, 2002).

Ulloa, M., La Hacienda Real de Castilla en el reinado de Felipe II (Madrid, 1977).

Vührer, A., Histoire de la dette publique en France (Paris, 1886).

Zabala Aguirre, P., Las alcabalas y la Hacienda Real en Castilla. Siglo XVI (Santander, 2000). 